Keywords:

Uranates,

Sodium boltwoodite,

Sodium weeksite,

Uranophane

\title{
Conditions Conducive to Forming Crystalline Uranyl Silicates in SRS Evaporators.
}

Author: L. N. Oji

Publication Date: January 8, 2004

Westinghouse Savannah River Company Savannah River Site

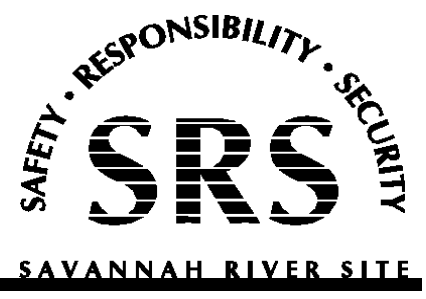


This page was intentionally left blank 
This document was prepared in conjunction with work accomplished under Contract No. DE-AC09-96SR18500 with the U. S. Department of Energy.

\section{DISCLAIMER}

This report was prepared as an account of work sponsored by an agency of the United States Government. Neither the United States Government nor any agency thereof, nor any of their employees, makes any warranty, express or implied, or assumes any legal liability or responsibility for the accuracy, completeness, or usefulness of any information, apparatus, product or process disclosed, or represents that its use would not infringe privately owned rights. Reference herein to any specific commercial product, process or service by trade name, trademark, manufacturer, or otherwise does not necessarily constitute or imply its endorsement, recommendation, or favoring by the United States Government or any agency thereof. The views and opinions of authors expressed herein do not necessarily state or reflect those of the United States Government or any agency thereof.

This report has been reproduced directly from the best available copy.

Available for sale to the public, in paper, from: U.S. Department of Commerce, National Technical Information Service, 5285 Port Royal Road, Springfield, VA 22161, phone: (800) 553-6847, fax: (703) 605-6900

email: orders@ntis.fedworld.gov

online ordering: http://www.ntis.gov/help/index.asp

Available electronically at http://www.osti.gov/bridge

Available for a processing fee to U.S. Department of Energy and its contractors, in paper, from: U.S. Department of Energy, Office of Scientific and Technical Information, P.O. Box 62, Oak Ridge, TN 37831-0062,

phone: (865)576-8401,

fax: (865)576-5728

email: $\underline{\text { reports@ adonis.osti.gov }}$ 


\section{SUMMARY}

The laboratory conditions (temperature range of $80-150^{\circ} \mathrm{C}$, hydrothermal and oxidizing environment, soluble uranium and silica, atmospheric and $\mathrm{pH}$ conditions) under which synthetic uranyl silicates are made are almost identical to SRS evaporator conditions, with the exception of differences in sodium ion $\left(\mathrm{Na}^{+}\right)$concentration. Synthetic uranyl silicates have been made only under low $\mathrm{Na}^{+}$concentration $(<0.02 \mathrm{M})$, while attempts to synthesize uranyl silicates in this study in the presence of high $\mathrm{Na}^{+}$concentration $(5.6 \mathrm{M})$, which are typical of SRS evaporators have proved unfruitful.

In the presence of soluble silica and uranyl ion, uranyl silicates (sodium weeksite, sodium boltwoodite and uranophane) have been synthesized at moderately low to high $\mathrm{pH}$ in temperature ranges of $80-150{ }^{\circ} \mathrm{C}$ and at less than $0.02 \mathrm{M} \mathrm{Na}^{+}$ion concentration in the reaction mixtures. However, in the presence of high $\mathrm{Na}^{+}$concentration the main product distribution for the same soluble silica-uranium reaction mixture shifts towards the formation of clarkeite $\left(\mathrm{Na}\left[\left(\mathrm{UO}_{2}\right) \mathrm{O}(\mathrm{OH})\right]\left(\mathrm{H}_{2} \mathrm{O}\right)_{0-1}\right)$, a hydrated sodium uranate and not towards the formation of uranyl silicates.

There is a threshold $\mathrm{Na}^{+}$concentration requirement above which uranyl silicates are not formed under laboratory conditions that are quite similar to SRS evaporator conditions. This threshold $\mathrm{Na}^{+}$concentration, which is yet to be determined, may be influenced by the sodium-to-uranium ratio in a reaction mixture.

Therefore, based on the synthesis information presented in this study the following conclusions are made:

- Crystalline uranyl silicates are readily formed in the presence of dissolved uranium and silica.

- The presence of high $\mathrm{Na}^{+}$concentration in a reaction mixture of dissolved uranium and silica inhibits the formation of crystalline uranyl silicates.

- The reaction path way favors the formation of hydrated sodium uranates over the uranyl silicates in a reaction mixture with high $\mathrm{Na}^{+}$concentration.

- Crystalline uranyl silicate minerals are not easily produced under SRS evaporator conditions because of high $\mathrm{Na}^{+}$concentration in the evaporators and in the evaporator feed tanks.

- The principal uranium minerals which could be produced under evaporator conditions are sodium uranium minerals or clarkeite, which could also exist in the dehydrated form called sodium uranate. 


\section{TABLE OF CONTENTS}

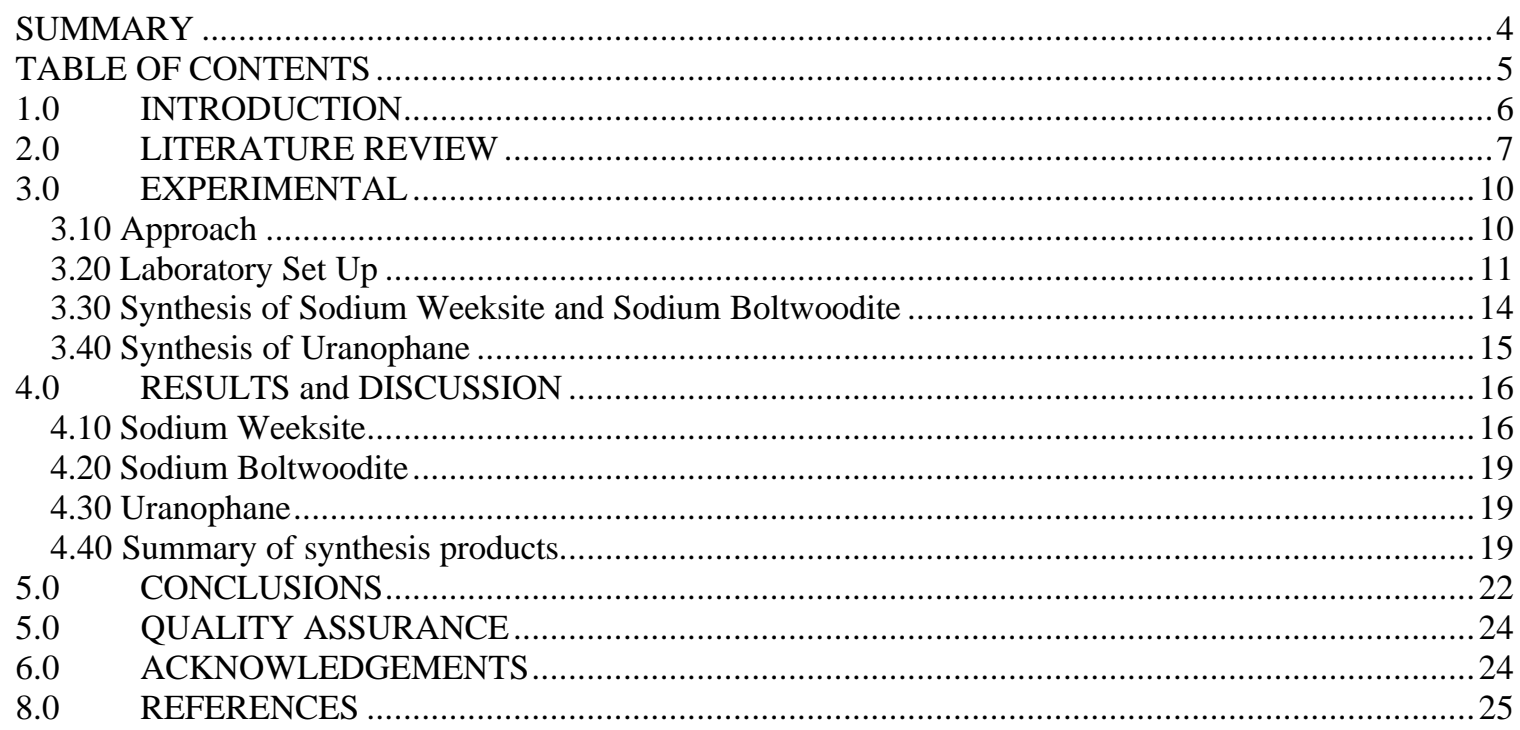

\section{LIST OF FIGURES}

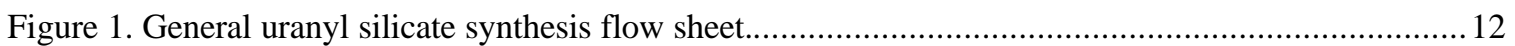

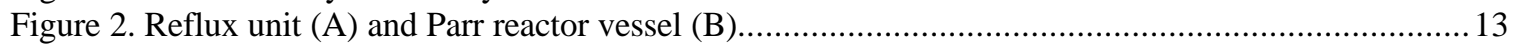

Figure 3. Characterization of solids from weeksite synthesis for synthesis using low $\mathrm{Na}^{+} \ldots \ldots \ldots \ldots \ldots \ldots \ldots \ldots . . . . . .17$

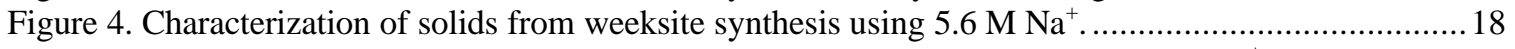

Figure 5. Characterization of solids from boltwoodite synthesis in the presence of low $\mathrm{Na}^{+}(\mathrm{A}, \mathrm{B}) \ldots \ldots \ldots .21$

Figure 6. Characterization of solids made using the uranophane synthesis method made with ..................22

\section{LIST OF TABLES}

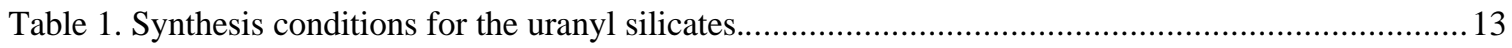

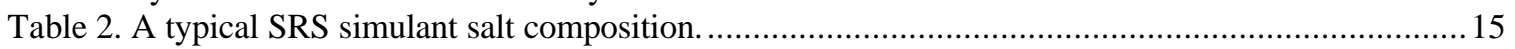

Table 3. Laboratory synthesis condition for the uranyl silicates versus evaporator operating conditions.... 15

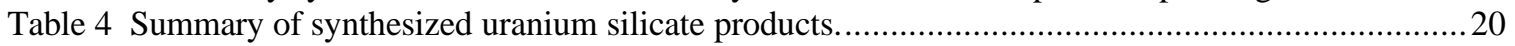




\subsection{INTRODUCTION}

The High-Level Waste Tank Farms stores and process high-level liquid wastes from a number of sources including $\mathrm{F}$ and $\mathrm{H}$ Area Canyons and a recycle stream from the Defense Waste Processing Facility (DWPF). The waste is relatively dilute as received and is concentrated in one of several evaporators to minimize the space required to store the waste. The concentrated waste is transferred to one of several concentrate receipt tanks for storage. Recently, the 2H-Evaporator was shut down due to crystallization of sodium aluminosilicates (NAS), such as zeolite A, sodalite and cancrinite in the evaporator and the precipitation of enriched uranium with the NAS. ${ }^{1,2,3}$

One option for controlling the crystallization of NAS in the evaporators requires a segregation of silicon-containing waste fed to the $2 \mathrm{H}$ Evaporators. But in the absence of aluminosilicates, there exists the potential for the formation of other solids from the interaction of dissolved uranium with dissolved silica. Recently, the characterization of solid phases formed in studies dealing with the formation of sodium aluminosilicate phases in SRS evaporators showed possible amorphous uranyl silicate solid phases associated with bulk aluminosilicate phases. ${ }^{4,5}$

Thus, if the above observation proves to be true, the segregation of silicon-rich waste, which still contains significant amounts of dissolved uranium, may actually enhance the formation of insoluble uranyl silicates when fed into the evaporators. The existence of such uranyl silicates may also help account for the relatively significant amount of uranium that was observed as part of the $2 \mathrm{H}$ Evaporator scaling. Additional understanding of the formation mechanisms and the type of uranyl silicates formed under evaporator conditions, if any, will also assist in providing the technical baseline for the operation of the $2 \mathrm{H}$ Evaporator.

In the evaporator storage feed tanks, which are hydrated and oxidizing environments, uranium exists in the $\mathrm{U}^{+6}$ oxidation state as the uranyl cation $\left(\mathrm{UO}_{2}{ }^{2+}\right)$ and secondary $\mathrm{U}^{+6}$ minerals such as the uranyl oxide hydrates like schoepite $\left(\mathrm{UO}_{3} 2 \mathrm{H}_{2} \mathrm{O}\right)$ and sodium uranates $\left(\mathrm{Na}_{2} \mathrm{UO}_{4}\right.$ or $\left.\mathrm{Na}_{2} \mathrm{U}_{2} \mathrm{O}_{7}\right)$. Depending on the chemistry of the feed tanks and the presence or absence of other cations like dissolved silica, calcium and magnesium, the hydrated uranium phases may further transform into other uranium minerals. The goal of this study is to identify evaporator conditions that are conducive to the formation of crystalline uranyl silicates in SRS evaporators. This investigation is divided into the following tasks:

- Literature reviews to determine conditions in which uranyl silicates are known to form and screening of these conditions for applicability to SRS High Level Waste evaporators and identification of possible formation mechanisms, and

- Performing of laboratory synthesis to determine if uranyl silicates form under the selected evaporator conditions. 


\subsection{LITERATURE REVIEW}

In nature uranium silicates are formed in silica-rich ground water where dissolved uranium is present. The natural conditions for the precipitation of uranium silicate can vary from low to high $\mathrm{pH}$ conditions and from low parts per billion levels of divalent or univalent transition metals to the milligram levels. In an oxidizing environment, uranium exists in the $\mathrm{U}(+\mathrm{VI})$ oxidation state and forms the uranyl ion $\mathrm{UO}_{2}{ }^{2+}$ in the presence of aerated solutions. $^{7}$ The uranyl ion will also combine with other soluble and dissolved ions like silica to form uranyl solid phases. At higher $\mathrm{pH}$ conditions, the uranyl ion may hydrolyze into a number of aqueous hydroxide complexes. These polymeric hydroxy uranyl complexes, under moderate temperatures conditions will combine with soluble silica to form various insoluble uranyl silicate minerals. ${ }^{8}$

There is lot of literature information about conditions that favor the formation of uranium silicates in the environment. However, although some of these conditions are quite similar to the evaporator conditions in many ways. One important condition which is unique to the evaporator system is the high sodium ion $\left(\mathrm{Na}^{+}\right)$concentration averaging about 5.6 molar, which plays an important role in determining the nature of the final uranium mineral produced. Since the conditions in SRS evaporators are oxidizing, uranium bearing silicate minerals in the evaporators are most likely to exist in the oxidized uranyl ion form $\left(\mathrm{U}^{6+}\right)$. In these oxidizing environments the uranyl ion may be much more soluble depending on the solution chemistry $\left(\mathrm{Na}^{+}\right.$concentration) and the uranyl phases present in the evaporator liqueur. Under laboratory conditions, this high ionic strength and high caustic conditions may greatly reduce the solubility of uranyl and possibly silica, too. Both natural and laboratory synthesis conditions for uranyl silicates requires a stage where both uranium and silicon are soluble. ${ }^{9}$ One would therefore expect low yield for uranyl silicate formation, if any, under such high $\mathrm{Na}^{+}$concentration.

Essentially, three general approaches have been used by researchers to produce synthetic uranyl silicates under laboratory conditions. By far the most widely used technique involves the direct reaction between dissolved silica and uranyl ion species. ${ }^{10,11,12}$ This normally involves the aging of the reaction mixture for several hours or even days, with $\mathrm{pH}$ adjustment in some cases, followed by isothermal treatment of the mixture at temperatures usually between 80 and $150{ }^{\circ} \mathrm{C}$ for several days to enhance the crystallographic features of the synthetic mineral. After thermal treatment and solidliquid separation, the material is washed with distilled and deionized (ultrapure) water and dried at room temperature or at higher temperatures depending on the nature of the silicate being synthesized. In certain cases, some uranyl silicates can be synthesized by starting with a non-uranyl silicate solid phase material as the starting reagent. For example, soddyite $\left(\left(\mathrm{UO}_{2}\right)_{2} \mathrm{SiO}_{4} \cdot 2 \mathrm{H}_{2} \mathrm{O}\right)$ can be synthesized by starting with a uranyl oxidehydrate like schoepite $\left(\mathrm{UO}_{2}(\mathrm{OH})_{2}\right) \cdot 2 \mathrm{H}_{2} \mathrm{O}$ suspended in a solution of sodium silicate at $100{ }^{\circ} \mathrm{C} .{ }^{13} \mathrm{~A}$ third and rarer technique involves vapor phase hydration experiments ${ }^{14}$ on uranium-doped borosilicate waste glass at elevated temperatures of about $200{ }^{\circ} \mathrm{C}$.

The synthesis methods summarized thus far are applicable mostly in the synthesis of three categories of uranyl silicate minerals: simple hydrated uranyl silicates like soddyite, 
alkali-based uranyl silicates like sodium boltwoodite $\left(\mathrm{Na}\left(\mathrm{H}_{3} \mathrm{O}\right)\left(\mathrm{UO}_{2}\right) \mathrm{SiO}_{4} \mathrm{H}_{2} \mathrm{O}\right)$ and alkali-earth uranyl silicates like uranophane $\left(\mathrm{Ca}\left(\mathrm{H}_{3} \mathrm{O}\right)_{2}\left(\mathrm{UO}_{2}\right)_{2}\left(\mathrm{SiO}_{4}\right)_{2} \cdot \mathrm{H}_{2} \mathrm{O}\right)$.

The reaction mechanisms by which uranyl silicates or other insoluble uranium minerals are formed are not sufficiently understood because of the lack of thermodynamic data necessary to predict their stability. However, through the use of semi-empirical methods for estimating free energies and enthalpies of formation, ${ }^{15,16}$ acceptable data for stability of certain uranyl silicate solid phases has been predicted. In this model uranyl hydrolysis products such as schoepite are expected to predominate when dissolved silicate is low. However, when silicate concentrations exceed approximately $1 \times 10^{-4} \mathrm{M}$, uranyl silicate phases such as soddyite, sodium weeksite and uranophane are predicted to be the thermodynamically favored solids.

The review here focuses on the reaction of dissolved uranyl ion and dissolved silica to produce uranyl silicates in an oxidizing environment. The operational conditions for SRS Evaporators are summarized in Table 2. The maximum operation temperature is about $150{ }^{\circ} \mathrm{C}$. The interest lies only in those synthetic crystalline uranyl silicate phases, which can exist at or below this maximum temperature in a high caustic, oxidizing environment of the evaporators.

While the emphasis of this study is on the formation of uranyl silicates in the evaporators, it is important to mention amorphization or disordering of uranyl silicate structures that may occur in the evaporators as a result of their exposure to radiation conditions of the evaporator waste content. Uranyl silicates formed during evaporator operation or in the evaporator feed tanks, if any, will be subject to a high radiation field, a combination of high irradiation flux from $\alpha, \beta$-particles and $\gamma$-rays from nuclear waste, that can result in substantial changes in internal structure of such silicates. The secondary end product from such oxidizing and radiation environment will be a variety of uranyl oxyhydroxides, silicates and other uranium compounds. ${ }^{17}$ Although only a few literature citings are available dealing with the effects of ionizing radiation on uranyl silicate phases $^{18}$, it is quite obvious that uranyl silicate structures become disordered in the presence of very high ionizing radiation fields. For examples, studies performed with uranophane exposed to high ionizing radiation shows that there is gradual disordering or amorphization (i.e., conversion from crystalline to amorphous) of the entire uranyl sheet silicate structure at room temperature. Amorphization dose for uranophane at room temperature has been reported to be $1.3 \times 10^{12} \mathrm{rad}^{18}$ Based on an SRS evaporator maintenance cycle of three months on the average, and an average evaporator radiation dose rate of $1.30 \mathrm{E}+3 \mathrm{rad}$ per hour (based on the predominant radionuclide, Cs-137 at one curie per liter), one can estimate the maximum ionizing radiation minerals formed in the evaporator would be exposed to. This value is approximately $2.8 \mathrm{E}+06 \mathrm{rad}$. Thus, although the ionization conditions at SRS evaporators can be relatively high, they are normally several orders of magnitude lower than the amorphization dose reported for uranophane. 
A mechanism for the radiation/ionization-induced amorphization of minerals comprising of $\mathrm{SiO}_{2}$ has been suggested. ${ }^{19}$ This mechanism involves heterogeneous nucleation and growth of disordered strain centers and final gradual homogeneous disordering in the remaining matrix. The mechanism is based on a model of radiolysis, which leads to instability of $\mathrm{Si}-\mathrm{O}$ bonds due to electronic excitation and breaking of bonds and the formation of peroxy linkages at other oxygen sites.

In this literature summary, the conditions under which uranyl silicates are known to form under laboratory conditions have been examined. The emphasis has been on those uranyl silicates whose synthesis conditions and general chemical formula reflect SRS evaporator conditions and reagent precursors present at the evaporators. The uranyl silicates selected for laboratory synthesis evaluations are thus required to meet most of the following criteria, which reflect evaporator conditions at SRS:

- Minerals where the uranium atom is in the oxidized uranyl ion form

- Molecular structures containing one or several of the predominant cations present in the evaporators.

- Can be synthesized at high $\mathrm{pH}$ and exist at either low or high $\mathrm{pH}$ conditions.

- Can be synthesized even at low temperatures and still maintain their crystalline structure at high temperatures of $<150{ }^{\circ} \mathrm{C}$.

There are several naturally occurring uranyl silicates that can be made under laboratory conditions and in the operating temperatures of the evaporators at SRS. Based on the summarized selection criteria above, uranyl silicate minerals that meet most of the selection criteria for this evaporator study can be classified into three main categories:

- Hydrated uranyl silicates, which include uranyl silicates with no transition metal cations in their chemical structure for example, swamboite $\left(\mathrm{U}^{6+}\left(\mathrm{UO}_{2}\right)_{6}\left(\mathrm{SiO}_{3} \mathrm{OH}\right)_{6}\left(\mathrm{H}_{2} \mathrm{O}\right)_{30}{ }^{20}\right.$

- Alkali uranyl silicates with monovalent cations in their chemical structure. Some of these include sodium boltwoodite $\left(\mathrm{Na}\left(\mathrm{H}_{3} \mathrm{O}\right)\left(\mathrm{UO}_{2}\right) \mathrm{SiO}_{4} \cdot \mathrm{H}_{2} \mathrm{O}\right)$, sodium weeksite $\left(\mathrm{Na}_{2}\left(\mathrm{UO}_{2}\right)_{2}\left(\mathrm{Si}_{2} \mathrm{O}_{5}\right)_{3} \cdot 7 \mathrm{H}_{2} \mathrm{O}\right)^{21}$ and potassium hydrous alkali uranyl silicates $\left(\mathrm{K}_{2}\left(\mathrm{UO}_{2}\right)_{2} \mathrm{Si}_{6} \mathrm{O}_{15} \cdot 4 \mathrm{H}_{2} \mathrm{O}\right)$ and $\left.\left(\mathrm{H}_{3} \mathrm{O}\right) \mathrm{K}\left(\mathrm{UO}_{2}\right)\left(\mathrm{SiO}_{4}\right) \cdot \mathrm{H}_{2} \mathrm{O}\right){ }^{22}$

- Alkali-earth uranyl silicates with divalent cations in their chemical structure. In this class there only two important minerals, alpha- and beta-uranophane $\left(\mathrm{Ca}\left(\mathrm{H}_{3} \mathrm{O}\right)_{2}\left(\mathrm{UO}_{2}\right)_{2}\left(\mathrm{SiO}_{4}\right)_{2} \cdot \mathrm{H}_{2} \mathrm{O}\right)$, which are dimorphs that can only be distinguished through X-ray diffraction (XRD) characterization. ${ }^{11}$

Although uranyl silicate can be synthesized even at room temperatures when dissolved silica and uranyl ion species are combined, the desired uranyl silicate mineral with distinct crystallographic features are only produced with an increase in reaction temperatures or prolonged heating. ${ }^{23}$ 
Sodium boltwoodite ${ }^{24}$, is synthesized at moderately high $\mathrm{pH}$ condition of 10 and above and temperatures ranging from 90 to $150{ }^{\circ} \mathrm{C}$. Sodium weeksite is also synthesized at moderate $\mathrm{pH}$ conditions at temperatures ranging from 100 to $150{ }^{\circ} \mathrm{C} .{ }^{10}$ Uranophane is the only uranyl silicate mineral that can be synthesized at a wide range of $\mathrm{pH}$ conditions ranging from $\mathrm{pH} 1$ to 13 . The synthesis temperatures for uranophane ${ }^{11}$ are between 100 and $150{ }^{\circ} \mathrm{C}$.

Both sodium boltwoodite and sodium weeksite are uranyl silicates produced under moderately high $\mathrm{pH}$ and temperature conditions, which are similar to the oxidizing environments of the evaporators. They are included as possible candidates of uranyl silicates that can be produced under evaporator conditions. Uranophanes occur in nature in the oxidation zones of hydrothermal uranium deposits and their laboratory synthesis condition are comparable with oxidizing environments of the evaporators and thus are considered as possible uranyl silicate products from the evaporators.

High temperature uranates (temperatures $>250{ }^{\circ} \mathrm{C}$ ) like potassium hydrous alkali uranyl silicate $\left(\mathrm{K}_{2}\left(\mathrm{UO}_{2}\right)_{2} \mathrm{Si}_{6} \mathrm{O}_{15} \cdot 4 \mathrm{H}_{2} \mathrm{O}\right)$, potassium hydrous alkali uranate $\left(\left(\mathrm{H}_{3} \mathrm{O}\right) \mathrm{K}\left(\mathrm{UO}_{2}\right) \mathrm{SiO}_{4} \cdot \mathrm{H}_{2} \mathrm{O}\right)$ and potassium-sodium alkali uranates $\left(\mathrm{KNa}_{3}\left(\mathrm{UO}_{2}\right)_{2}\left(\mathrm{Si}_{4} \mathrm{O}_{10}\right)_{2}\left(\mathrm{H}_{2} \mathrm{O}\right)_{4}\right)^{14}$ are excluded from synthesis consideration in this study because, although there is the possibility of their being formed near heating coils in the evaporator, the heating coil temperatures do not represent the average evaporator temperatures. Based on process knowledge evaporator heating coil temperatures can approach $250^{\circ} \mathrm{C}$.

In summary, therefore, the plan is to synthesize these selected uranyl silicates (sodium weeksite, sodium boltwoodite and uranophane) under conditions which are similar to that of SRS evaporators and spectroscopically confirm their mineralogical identities.

\subsection{EXPERIMENTAL}

\subsection{Approach}

The general procedure used in the hydrothermal synthesis of the uranyl silicates is summarized in the flow sheet in Figure 1. In the synthesis of sodium boltwoodite and sodium weeksite, stoichiometric amounts of uranium and silicate precursors (uranium acetate and sodium silicate nonahydrate) were mixed for a given length of time depending on which of the silicates was being synthesized as summarized in Table 1. After $\mathrm{pH}$ adjustment, the mixture was refluxed for a length of time. After this step, the decision was made whether to perform a solid liquid separation and wash the resulting precipitate in ultrapure water several times before introducing the precipitate with ultrapure water into the Parr reactor at a given temperature or to send the unwashed precipitate and the reaction mixture directly into the Parr reactor (representing evaporator conditions). 
In the synthesis of uranophane, an additional ingredient, calcium as calcium acetate, was added into the mixture also in stoichiometric amounts and the procedure repeated as above. Per the flow sheet in Figure 1, steps 1, 2, 4, 5 and 6 reflects the standard laboratory methods for making purified synthetic uranyl silicates, while steps $1,2,7$ and 8 reflect evaporator condition products, which will normally not be purified minerals, if produced at all in the evaporator.

To make any of the silicates one could either start the synthesis with the materials as described above with ultrapure water added to the reaction mixture to adjust the final reaction volume to $300 \mathrm{~mL}$ or with an additional $100-150 \mathrm{~mL}$ of a typical SRS stimulant salt solution added to a bring the $\mathrm{Na}^{+}$concentration to $5.6 \mathrm{M}$. The last approach, referred to as high $\mathrm{Na}^{+}$synthesis, is one of the most important evaporator conditions. The final volume of each reaction mixture for every synthesis was $300 \mathrm{~mL}$. This volume was chosen because of safety limitations on the Parr reactor used for the final phase of the synthesis. The reagents grade chemicals and precursors used as starting materials for the silicate synthesis were uranium acetate (Alpha Aesar), sodium metasilicate nonahydrate (Sigma) and calcium acetate (Alpha Aesar). Stock solution was made up with compositions of $0.1 \mathrm{M}$ solutions of the above chemical reagents.

\subsection{Laboratory set up}

The standard laboratory reflux vessel used for first part of the mixing and reflux reactions in the uranium silicate synthesis, Figure 2 A, consisted of a one-L stainless steel reaction vessel equipped with a Pyrex ${ }^{\circledR}$ glass lid cover, which was machined to bear an o-ring grove. The domed glass lid, bearing an o-ring rubber seal, was secured onto the one-liter reaction vessel with an adjustable clamp assembly (Duran reaction clamp). The top portion or lid contained appropriate glass receptacles and ports for a reflux condenser unit, an electric stirrer shaft in the center, a thermocouple and a covered reagent/sampling port. The digital read-out overhead electric stirrer (Fisher) featured two variable speed ranges (60 to 500 and 240 to $2000 \mathrm{rpm}$ ). A 46-cm long plastic stirring shaft, rotating at up to $200 \mathrm{rpm}$, was used to keep the reactor contents well mixed. The reaction precipitates, recovered after mixing and reflux reactions in the reflux unit was fed together with ultra pure water into the pressure reactor for enhanced crystallization of the silicates. The pressure reaction unit used for the long crystallization reaction phase for the uranyl silicates, Figure 2B, was a fixed-head high pressure Parr reactor rated for use at up to 1900 psi at $350^{\circ} \mathrm{C}$. The fixed-head vessel was equipped with the following:

1. Gas inlet/liquid sampling port with valves and dip tube

2. Pressure gage, 0-600 psi, with relief valve

3. Safety rupture disc, INC, $1000 \mathrm{psi}$

4. Gas release valve

5. Serpentine cooling coil

6. Thermowell, with Type-J thermocouple

7. Magnetic stirrer with 16 in-lb torque. and

8. A 780 Watt, $115 \mathrm{~V}$ electrical heater 
Reagents mixed for a given length of time.

\section{STEP 1}

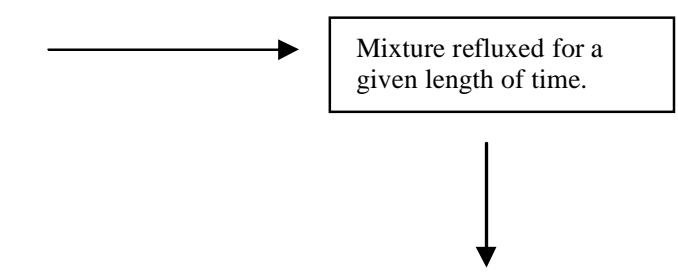

STEP 2

YES

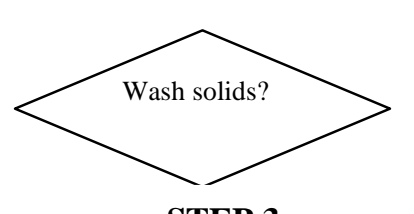

NO

STEP 3

Solids/liquid separation and solids washed $3 \mathrm{X}$

Mixture introduced directly into Parr Reactor

\section{STEP 7}

After washing solid fraction plus DI water is introduced into the Parr reactor for at a given temperature and reaction time.

STEP 5
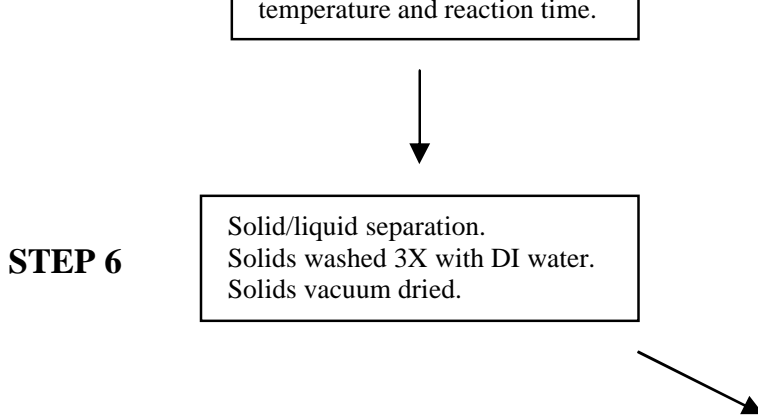

Solids/liquid separation and solids recovered vacuum dried.

Figure 1. General uranyl silicate synthesis flow sheet.

The Parr reactor was equipped with a variable-speed, explosion-proof, 1/4 hp motor, an electrical barrier box for thermocouples, pressure, and rpm signals, and a model 4843 controller, equipped with the following:

1. PID, programmable, temperature controller

2. Manual speed adjust knob, 0-600 rpm

3. Digital tachometer display

4. Digital pressure display

5. High temperature limit

6. Solenoid valve module 
The reaction vessel itself was made of inconel-600 and designed and equipped with a removable $600-\mathrm{mL}$ Teflon ${ }^{\circledR}$ insert liner for holding reagents during synthesis. The maximum pressure recorded during a typical synthesis, at $150{ }^{\circ} \mathrm{C}$ with $300 \mathrm{~mL}$ reagent solution charged into the reaction vessel, was 51 psi with an average pressure read out of $48 \pm 2$ psi over 96 hours of operation.

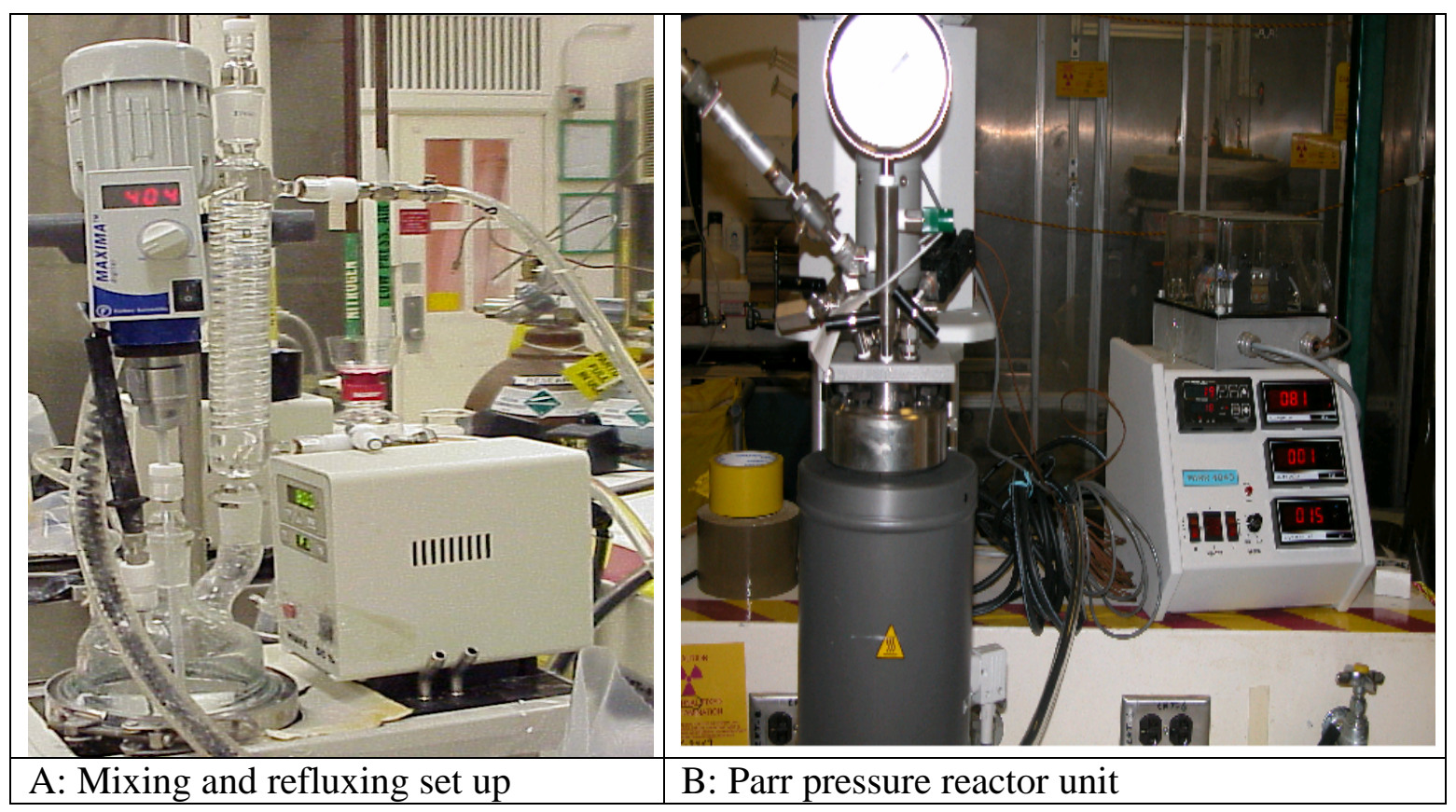

Figure 2. Reflux unit (A) and Parr reactor vessel (B).

Table 1. Synthesis conditions for the uranyl silicates.

\begin{tabular}{|c|c|c|c|c|c|c|}
\hline $\begin{array}{l}\text { Target } \\
\text { Uranyl } \\
\text { Silicate }\end{array}$ & $\begin{array}{l}\text { Mixing } \\
\text { Time, } h\end{array}$ & pH & $\begin{array}{l}\text { Reflux } \\
\text { Temp. }{ }^{\circ} \mathrm{C}\end{array}$ & $\begin{array}{l}\text { Reflux } \\
\text { Time, h }\end{array}$ & $\begin{array}{l}\text { Parr Reactor } \\
\text { Temperature, } \\
{ }^{\circ} \mathrm{C}\end{array}$ & $\begin{array}{l}\text { Parr Reactor } \\
\text { Synthesis } \\
\text { Duration, } \\
\text { Days }\end{array}$ \\
\hline $\begin{array}{l}\text { Sodium } \\
\text { Weeksite }\end{array}$ & 2 & $8.5,>13$ & 100 & 72 & 150 & 4 \\
\hline $\begin{array}{l}\text { Sodium } \\
\text { Boltwoodite }\end{array}$ & 2 & $10.5,>13$ & 90 & 24 & 150 & 4 \\
\hline Uranophane & 4 & $8,>13$ & 90 & 24 & 118 & 4 \\
\hline
\end{tabular}




\subsection{Synthesis of sodium weeksite and sodium boltwoodite}

The laboratory synthesis of most of the uranyl silicates requires a minimum of 10-11 days, with seven of these days for crystallizations only at an average temperature of 150 ${ }^{\circ} \mathrm{C}$ (see reference 10). Because of time constraints and funding issues, a way was sought to reduce the lengthy synthesis time required to make the uranyl silicates here at SRTC. The goal was to limit the synthesis time to at most half the time or less as detailed in the references above. A typical low $\mathrm{Na}^{+}$synthesis reactant solution for sodium weeksite and sodium boltwoodite was a mixture of $100 \mathrm{~mL}$ solution of uranium acetate $(0.1 \mathrm{M}), 50 \mathrm{~mL}$ of sodium silicate nonahydrate $(0.1 \mathrm{M})$ and $150 \mathrm{~mL}$ of ultrapure water. The $\mathrm{pH}$ of the reaction mixtures was raised with either ammonium hydroxide or carbonate free sodium hydroxide and lowered with acetic acid. The desired $\mathrm{pH}$ values were 8.5 for sodium weeksite and 10.5 for sodium boltwoodite.

In the first few trial syntheses for sodium weeksite, using low $\mathrm{Na}^{+}$concentration (less than $0.02 \mathrm{M} \mathrm{Na}^{+}$in the $100 \mathrm{~mL}$ of $0.1 \mathrm{M}$ solution of sodium silicate nanohydrate reagent) the total synthesis time was reduced to about 40 hours, with test sample (aliquot) taken out of the Parr reactor after 8 hours. This 8 -hour sample was washed and vacuum dried for several days before X-ray diffraction (XRD) and infrared (IR) characterizations (see Figure 3, insets A and B). The remaining sample in the Parr reactor was left at the $150{ }^{\circ} \mathrm{C}$ crystallization temperature for a total of 37 hours. This 37-hour sample was washed and vacuum dried as before prior to XRD and IR characterizations (Figure 3, inserts B, C and D). The same synthesis was repeated one more time. This time, the total $\mathrm{Na}^{+}$ concentration in the reaction mixture was adjusted to $5.6 \mathrm{M} \mathrm{Na}^{+}$with the stimulant salt solution (see Table 2). Sodium weeksite products were synthesized in stoichiometric amounts $\left(2 \mathrm{UO}_{2}\left(\mathrm{C}_{2} \mathrm{H}_{2} \mathrm{O}_{2}\right)_{2} \cdot 2 \mathrm{H}_{2} \mathrm{O}+\mathrm{Na}_{2} \mathrm{SiO}_{3} \cdot 9 \mathrm{H}_{2} \mathrm{O}\right)$.

The washing and solid/liquid separation of the crystallized silicate solids from the reagent liquor was time-consuming because of the colloidal dimensions $(<5 \mu \mathrm{m})$ of the uranium solid particles. On those occasions when the uranium solids formed needed to be washed and fast recovery of washed particles was essential, a series of decanting and washing steps was performed. In these steps, ultrapure water was re-introduced into the solids decanted fraction and stirred for fifteen minutes and allowed to settle for about two hours. After the settling time, the decanting process was repeated three more times to ensure that most of the reagent liquor had been removed in the washing process. The final solid fractions were then vacuum dried over night and air dried to constant weight. The samples which did not require washing at the end of synthesis were simply vacuum dried over night and air dried to constant weight.

In the synthesis of sodium boltwoodite at a $\mathrm{pH}$ of 10.5 the crystallization time in the Parr reactor was increased from 40 to 96 hours to minimize poor crystallization results observed in the 8-hour synthesis of sodium weeksite described above. Again, the synthesis was performed at two $\mathrm{Na}^{+}$concentration levels; a low level $\mathrm{Na}^{+}$concentration of less than $0.02 \mathrm{M}$ to a high of $5.6 \mathrm{M} \mathrm{Na}^{+}$. Three synthesis products were produced: synthesis of sodium boltwoodite at low $\mathrm{Na}^{+}$levels with the final product washed several times with ultrapure water before introduction into the Parr reactor to enhance 
crystallization for 96 hours at $150^{\circ} \mathrm{C}$, a second synthesis at low $\mathrm{Na}^{+}$levels, the washing step above was left out and a third synthesis, which was performed at high $\mathrm{Na}^{+}$level of $5.6 \mathrm{M}$, the washing step was also left out, too. All three sodium boltwoodite products were synthesized in stoichiometric amounts $\left(2 \mathrm{UO}_{2}\left(\mathrm{C}_{2} \mathrm{H}_{2} \mathrm{O}_{2}\right)_{2} \cdot 2 \mathrm{H}_{2} \mathrm{O}+\mathrm{Na}_{2} \mathrm{SiO}_{3} \cdot 9 \mathrm{H}_{2} \mathrm{O}\right)$.

\subsection{Synthesis of uranophane}

The reagent mixtures used for the synthesis of uranophane was similar to the mixtures used for the synthesis of both sodium weeksite and sodium boltwoodite with the addition of calcium acetate. It consisted of $50 \mathrm{~mL}$ of sodium silicate nonahydrate $(0.1 \mathrm{M}), 100 \mathrm{~mL}$ of uranium acetate $(0.1 \mathrm{M}), 50 \mathrm{~mL}$ of calcium acetate $(0.1 \mathrm{M})$ and $100 \mathrm{~mL}$ of ultrapure water. In reactions involving $5.6 \mathrm{M} \mathrm{Na}^{+}$concentration, the $100 \mathrm{~mL}$ ultrapure water was replaced with $100 \mathrm{~mL}$ of a typical SRS stimulant salt solution $\left(11.2 \mathrm{M} \mathrm{Na}^{+}\right)$, see Table 2 . The SRS stimulant salt solution was used to increase the $\mathrm{Na}^{+}$concentration in the reaction mixture from $<0.02 \mathrm{M} \mathrm{Na}^{+}$solution to about $5.6 \mathrm{M} \mathrm{Na}^{+}$. In the high salt synthesis, the reagent solutions were first mixed to enhance the formation of the desired products thereby minimizing precipitation reactions due to changes in solution $\mathrm{pH}$. The higher sodium salt solution was added after mixing the reagents for about 15 minutes.

Uranophane was synthesized in stoichiometric amounts $\left(2 \mathrm{UO}_{2}\left(\mathrm{C}_{2} \mathrm{H}_{2} \mathrm{O}_{2}\right)_{2} \cdot 2 \mathrm{H}_{2} \mathrm{O}+\right.$ $\left.\mathrm{Na}_{2} \mathrm{SiO}_{3} \cdot 9 \mathrm{H}_{2} \mathrm{O}+\mathrm{Ca}\left(\mathrm{C}_{2} \mathrm{H}_{3} \mathrm{O}_{2}\right)_{2} \cdot \mathrm{H}_{2} \mathrm{O}\right)$.

Table 2. A typical SRS simulant salt composition.

\begin{tabular}{|l|l|c|c|}
\hline \multicolumn{1}{|c|}{ Component } & Sodium wt., g & $\begin{array}{c}\text { Moles of } \\
\text { component }\end{array}$ \\
\hline Sodium nitrate & $\mathrm{NaNO}_{3}$ & 118 & 5.13 \\
\hline Sodium nitrite & $\mathrm{NaNO}_{2}$ & 20 & 0.87 \\
\hline Sodium sulfate & $\mathrm{Na}_{2} \mathrm{SO}_{4}$ & 40 & 0.87 \\
\hline $\begin{array}{l}\text { Sodium carbonate } \\
\text { monohydrate }\end{array}$ & $\mathrm{Na}_{2} \mathrm{CO}_{3} \cdot \mathrm{H}_{2} \mathrm{O}$ & 10 & 0.218 \\
\hline Sodium hydroxide & $\mathrm{NaOH}$ & 70 & 3.044 \\
\hline$\left[\mathrm{Na}^{+}\right], \mathrm{M}=11.22$ & & & \\
\hline
\end{tabular}

Table 3. Laboratory synthesis condition for the uranyl silicates versus evaporator operating conditions.

\begin{tabular}{|l|c|c|}
\hline Condition & SRS evaporator operation & Uranyl silicate synthesis \\
\hline Temperature, ${ }^{\circ} \mathrm{C}$ & $120-150$ & $80-150$ \\
\hline $\mathrm{pH}$ & $>12$ & $8.5-12$ \\
\hline Uranium oxidation state & $\mathrm{U}^{+6}$ & $\mathrm{UO}_{2}{ }^{2+}$, uranyl silicate species \\
\hline Pressure & Atmospheric & Atmospheric \\
\hline Dissolved ions & $\mathrm{U}, \mathrm{Si}, \mathrm{Na}, \mathrm{Ca}, \mathrm{K}$, etc. & $\mathrm{U}, \mathrm{Si}, \mathrm{Na}, \mathrm{Ca}$ \\
\hline Specific gravity $^{+}$ & $1.37-1.62$ & $>1.30$ \\
\hline $\mathrm{Na}^{+}$concentration & $5.6 \mathrm{M}$ & $<0.020 \mathrm{M}$ \\
\hline
\end{tabular}




\subsection{RESULTS and DISCUSSION}

\subsection{Sodium weeksite}

The XRD* and IR spectra of the sodium weeksite produced are shown in Figure 3, inserts $\mathrm{C}$ and D (overlay of IR spectra) and Figure 4, inserts A, B and D. This IR spectrum for the (low $\mathrm{Na}^{+}$) synthetic sodium weeksite, Figure 3, insert D (37 hour-sample), is almost identical to the published IR spectrum for synthetic weeksite. ${ }^{10,21}$

XRD characterization of the 8-hour sample shows that the material produced after 8 hours of synthesis is not crystalline (Figure 3 insert A.), while the 37-hour sample is fairly crystalline (Figure 3, insert C). The overlay of IR spectra, Figure 3, insert B, for both the 8 and 37-hour samples also shows that the 37 hour-sample has more IR spectra features, meaning distinct peaks after $1200 \mathrm{~cm}^{-1}$, compared to the 8-hour sample, which showed broad absorptions, characteristic of amorphous phases.

Figure 4, inserts A, B and D show, respectively, the XRD, IR and Raman spectra (Raman spectra, which complements IR spectra included for reference only) for the high $\mathrm{Na}^{+}$ synthesis product. Figure 4, insert $\mathrm{C}$ shows a photo of the synthesized compounds in small glass vials. From left to right, the first two vials are low $\mathrm{Na}^{+}$synthesis product samples and the last two vials are synthesis at high $\mathrm{Na}^{+}$concentrations. The color of the products changes from light yellowish-green crystals for low $\mathrm{Na}^{+}$synthesis products to brownish crystalline materials for the high $\mathrm{Na}^{+}$synthesis products. The brownish color is characteristic of clarkeite.

The XRD characterization of the solids made at low and high $\mathrm{Na}^{+}$concentrations using the weeksite synthesis method shows that they are, respectively, a mixture of sodium weeksite and other minor uranium oxide products $^{3}$ and either pure clarkeite $\left(\mathrm{Na}\left(\mathrm{UO}_{2}\right) \mathrm{O}(\mathrm{OH})\right)$ or a mixture of clarkeite and sodium nitrate (nitratine) and uranium oxide hydrate for the unwashed solids. The failure to make $100 \%$ sodium weeksite even after washing several times may be attributed to the significant reduction in synthesis time from an average of 240 hours to just less than 40 hours and difficulty encountered in washing the crystals.

The synthesis of this particular uranyl silicate (sodium weeksite) was only used as a test case in the synthesis, because the evaporator $\mathrm{pH}$ is by far greater than 8.5 , which is the synthesis $\mathrm{pH}$ for sodium weeksite.

\footnotetext{
* Question marks,?, on XRD spectra indicate the existence of unmatched and unidentified peaks.

${ }^{\ni}$ Minor products from low $\mathrm{Na}^{+}$synthesis included questionable XRD assignments matching studtite $\left(\mathrm{UO}_{4} \cdot 4 \mathrm{H}_{2} \mathrm{O}\right)$ mineral.
} 


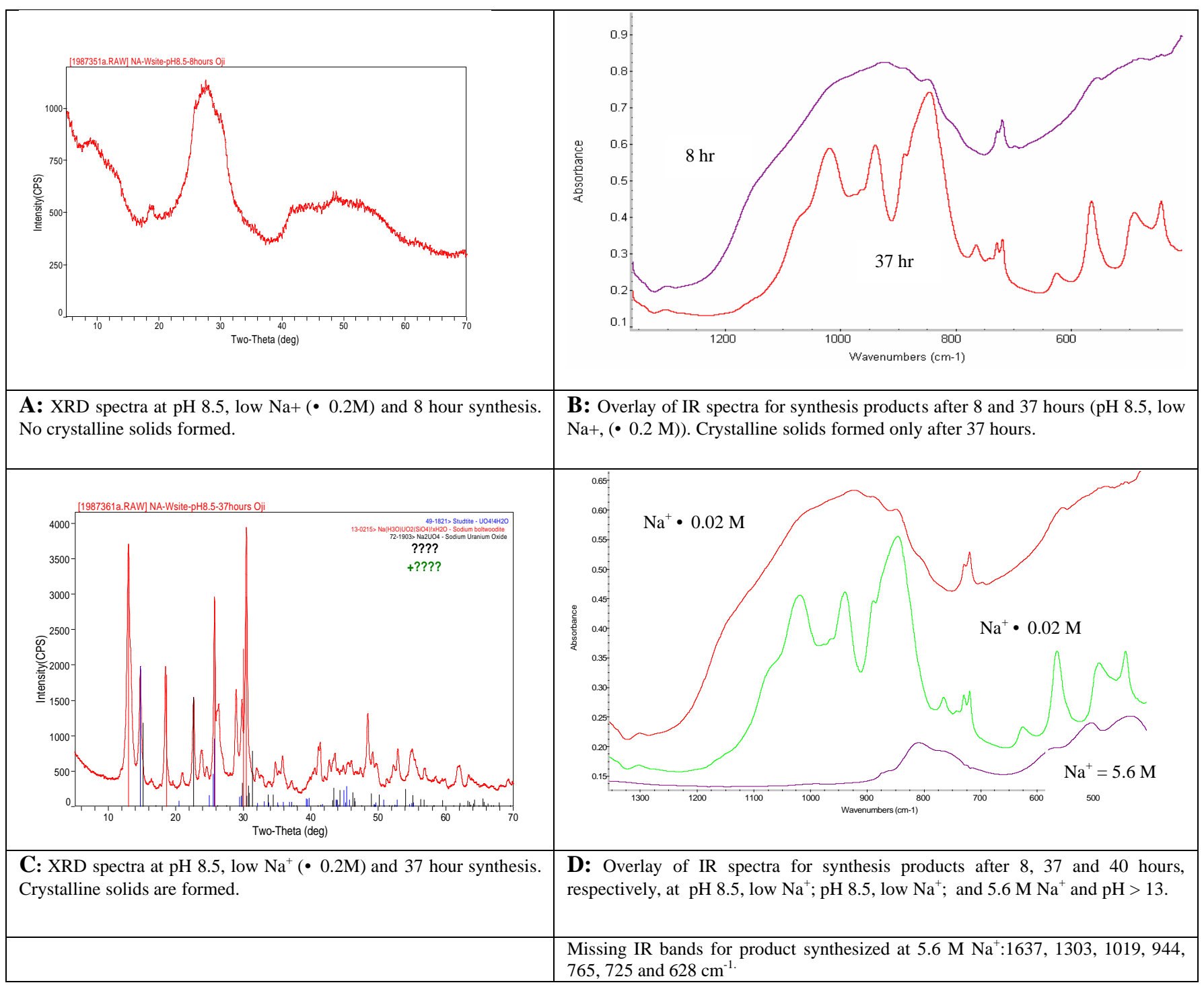

Figure 3. Characterization of solids from sodium weeksite synthesis based on low $\mathrm{Na}^{+}$. 

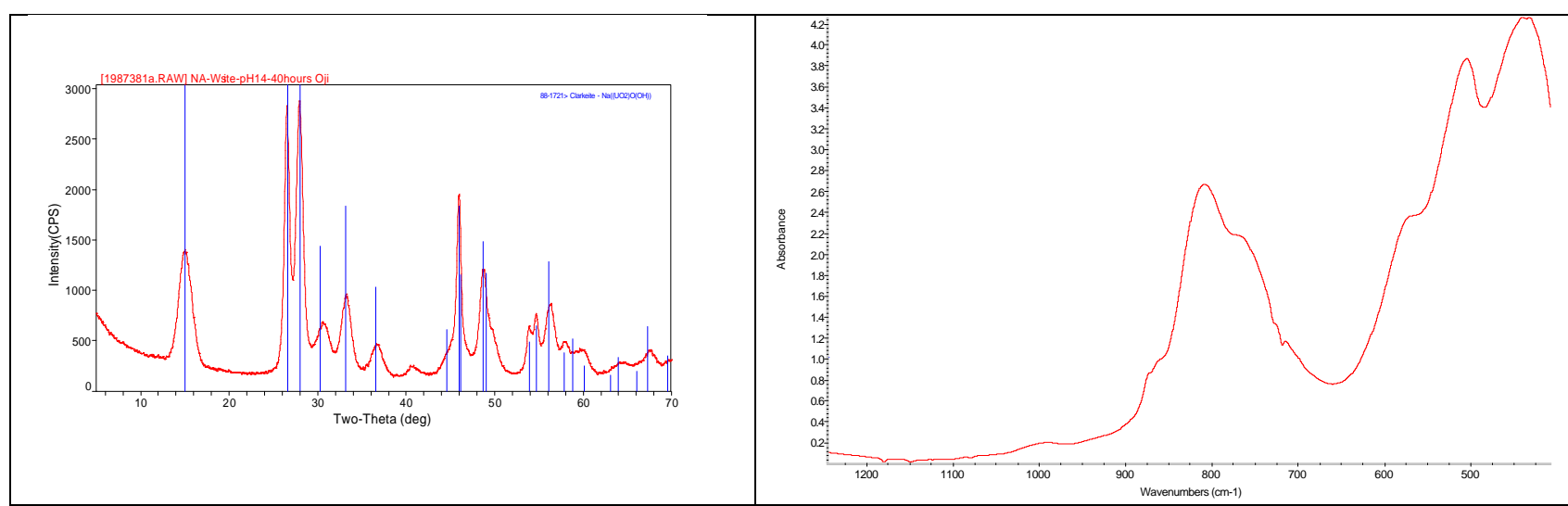

A: XRD spectra results at $\mathrm{pH} 14$ and $5.6 \mathrm{M}\left[\mathrm{Na}^{+}\right], 40$ hour reaction

B: IR spectra of synthesis product at $\mathrm{pH} 14$ and $5.6 \mathrm{M} \mathrm{Na}^{+}$and 40 hour time (evaporator conditions). Clarkeite is the only product. reaction time.

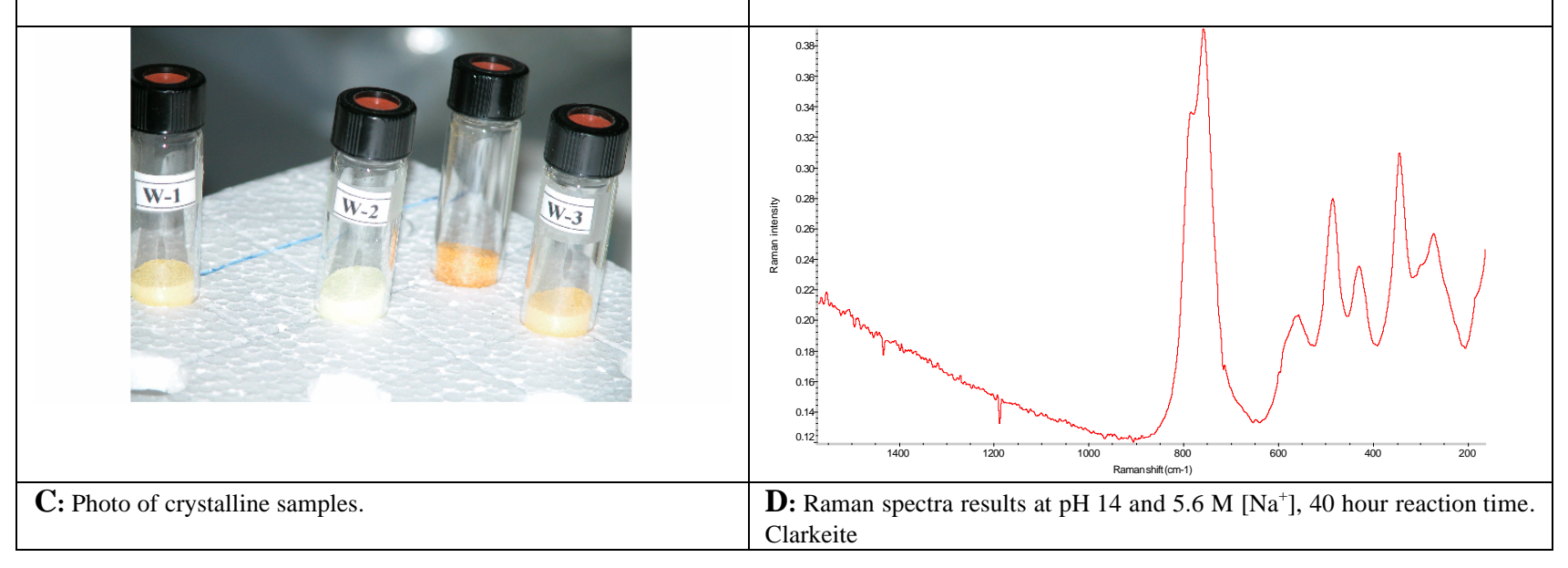

Figure 4. Characterization of solids from sodium weeksite synthesis based on $5.6 \mathrm{M}$ $\mathrm{Na}^{+}$. 


\subsection{Sodium boltwoodite}

The XRD and IR characterizations of the first two sodium boltwoodite products (Figure 5, inserts A, B and D and E) show that a crystalline yellow-green material was made. Both the washed and unwashed low level sodium synthesis produced sodium boltwoodite with impurities of uranium oxide. The third synthesis, a high sodium synthesis product, was a brownish precipitate instead of the golden yellow products as observed in the low sodium synthesis. XRD pattern matching showed that this high sodium synthesis product was clarkeite with uranium oxide impurities and not sodium boltwoodite Figure 5, insert $\mathrm{C}$ and $\mathrm{E}$.

Figure 5, insert D shows the overlay IR spectra for all three products (low $\mathrm{Na}^{+}$washed, low and high $\mathrm{Na}^{+}$unwashed products). This clearly shows that the high $\mathrm{Na}^{+}$unwashed product does not resemble the first two products. The following IR bands, characteristic of the products consisting of mostly sodium boltwoodite, are either completely missing or significantly reduced in intensity: 1637, 1303, 1019, 944, 765, 725 and $628 \mathrm{~cm}^{-1}$. These IR spectra for the low $\mathrm{Na}^{+}$synthetic sodium boltwoodites are almost identical to the published IR spectra for synthetic boltwoodite. ${ }^{10,13,21}$ The reference Raman ${ }^{25}$ spectrum for the sodium boltwoodite obtained in this synthesis was measured with laser light of a wavelength of $785 \mathrm{~nm}$. This Raman spectrum for sodium boltwoodite is similar to the

published Raman spectrum for synthetic sodium boltwoodite, ${ }^{25}$ although taken at different laser wave length of $1064 \mathrm{~nm}$.

\subsection{Uranophane}

Figure 6, inserts $\mathrm{A}$ and $\mathrm{B}$, show the XRD spectra for the products formed using the uranophane synthesis method at, respectively, low $\mathrm{Na}^{+}$concentration (uranophane) and high $\mathrm{Na}^{+}$concentration (clarkeite). The photo of the two crystalline products is shown in Figure 6, insert $\mathrm{C}$. The low $\mathrm{Na}^{+}$product is pale yellow-green while the high $\mathrm{Na}^{+}$product is brownish in color. The overlayed of IR spectra for the two products are shown in insert D. The IR spectra for the synthetic uranophane made at low $\mathrm{Na}^{+}$is identical to the published IR spectra for synthetic uranophane. ${ }^{10,26}$

The IR spectrum of the high $\mathrm{Na}^{+}$product (clarkeite) is almost devoid of any pronounced IR peaks or features at the characteristic IR "finger print" section for uranophane, below $1200 \mathrm{~cm}^{-1}$.

\subsection{Summary of synthesis products}

Table 4 shows a summary of the target uranium silicate minerals, the uranium solids produced and the synthesis conditions. In all cases, the target uranium mineral was produced except under conditions which involved high $\mathrm{Na}^{+}$concentration, which is a typical evaporator condition. In all high $\mathrm{Na}^{+}$concentrations synthesis the end products, irrespective of $\mathrm{pH}$ and reaction temperature factors, were always clarkeite. 
Table 4 Summary of synthesized uranium silicate products.

\begin{tabular}{|l|l|c|c|c|c|}
\hline \multicolumn{1}{|c|}{$\begin{array}{c}\text { Target mineral } \\
\text { product }\end{array}$} & \multicolumn{1}{|c|}{$\begin{array}{c}\text { Primary mineral } \\
\text { obtained }\end{array}$} & $\begin{array}{c}\text { Synthesis } \\
\text { temperature, } \\
\text { oC }\end{array}$ & pH & $\begin{array}{c}\text { Synthesis } \\
\text { Duration, } \\
\text { h. }\end{array}$ & $\begin{array}{c}\text { Sodium } \\
\text { concentration, } \\
\text { M }\end{array}$ \\
\hline Sodium weeksite & $\begin{array}{l}\text { Undefined } \\
\text { amorphous uranium } \\
\text { silicate }\end{array}$ & 150 & 8.5 & 8 & $<0.02$ \\
\hline Sodium weeksite & Sodium weeksite & 150 & 8.5 & 37 & $<0.02$ \\
\hline Sodium weeksite & Sodium weeksite & 150 & 8.5 & 40 & $\begin{array}{c}<0.02 \\
\text { (washed) }\end{array}$ \\
\hline Sodium weeksite & Sodium weeksite & 150 & 8.5 & 40 & $<0.02$ \\
(unwashed)
\end{tabular}




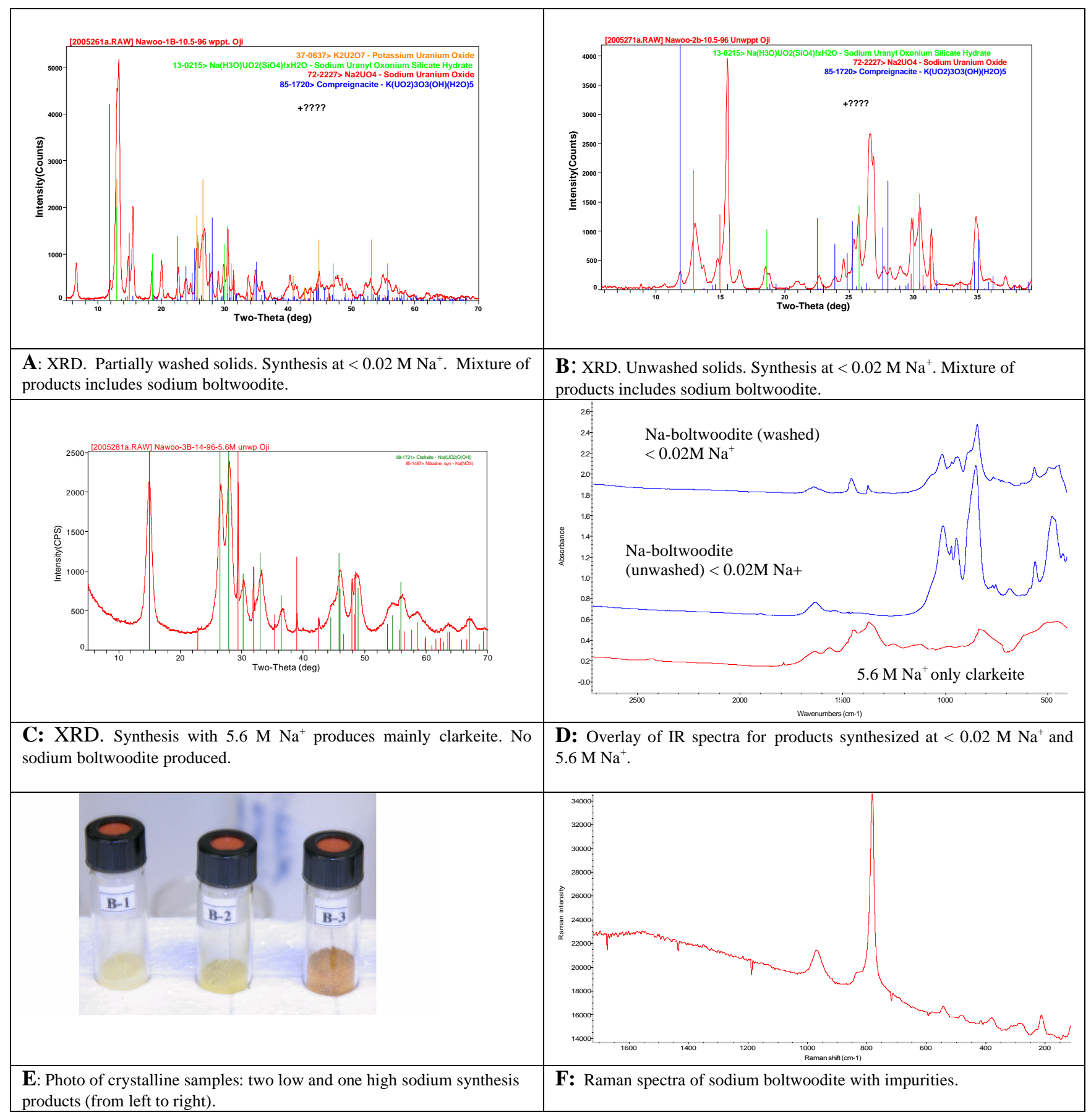

Figure 5. Characterization of solids made using sodium boltwoodite synthesis method in the presence of low $\mathrm{Na}^{+}(\mathrm{A}, \mathrm{B})$ and high $\mathrm{Na}^{+}(\mathrm{C})$. 


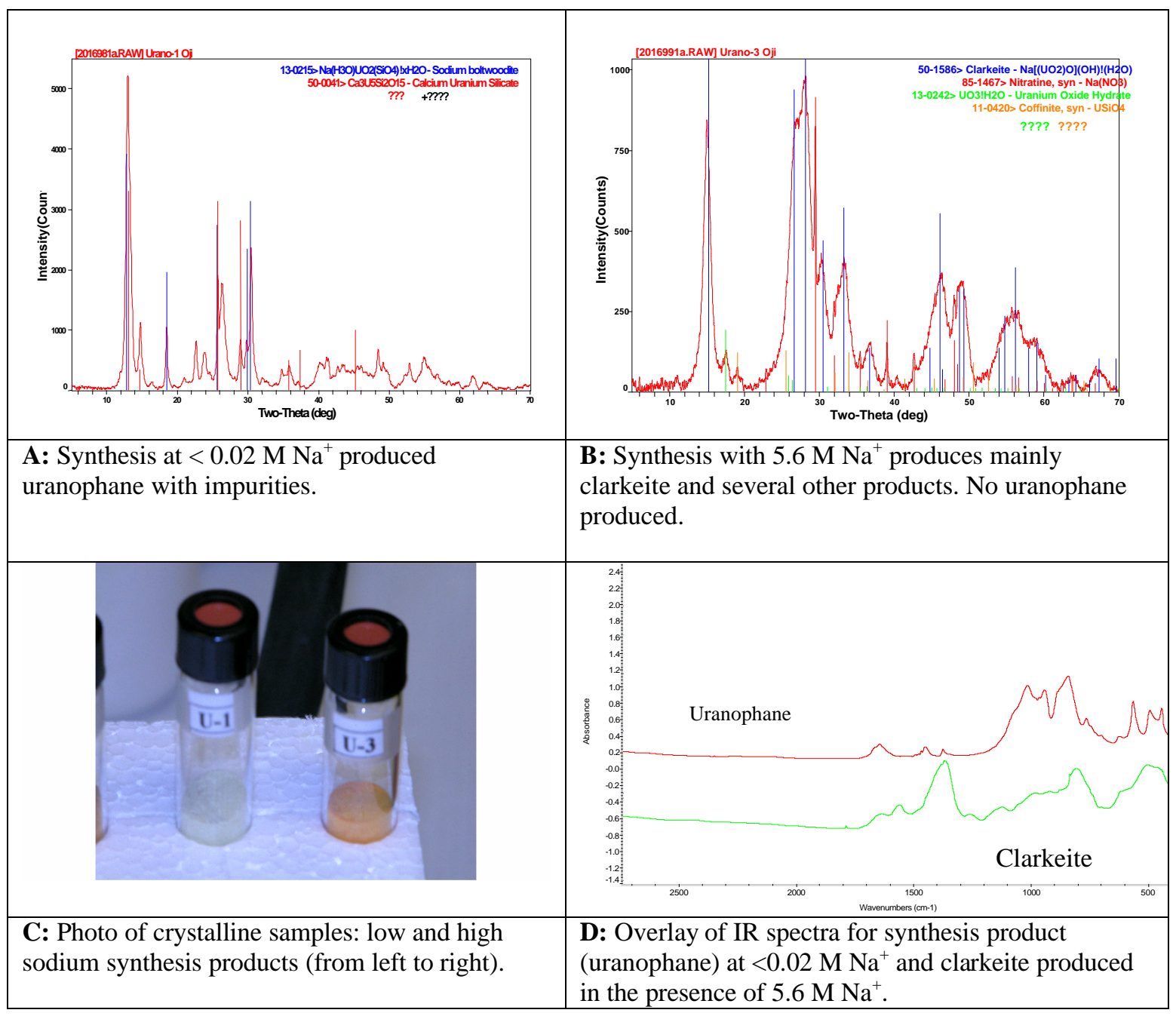

Figure 6. Characterization of solids made using the uranophane synthesis method in the presence of low $\mathrm{Na}^{+}(\mathrm{A})$ and high $\mathrm{Na}^{+}(\mathrm{B})$.

\subsection{CONCLUSIONS}

The laboratory conditions (temperature range of $80-150^{\circ} \mathrm{C}$, hydrothermal and oxidizing environment, soluble uranium and silica, atmospheric and $\mathrm{pH}$ conditions) under which synthetic uranyl silicates are made are almost identical to SRS evaporator conditions, with the exception of differences in $\mathrm{Na}^{+}$concentration. Synthetic crystalline uranyl silicates have been made only under low $\mathrm{Na}^{+}$concentration, while attempts to synthesize crystalline uranyl silicates in the presence of high $\mathrm{Na}^{+}$concentration, typical of SRS evaporators proved unfruitful.

Looking at all the uranium products synthesized in this study, it seems quite obvious that the amount or relative amount of sodium to uranium concentration determines whether uranyl silicate or the sodium-uranium mineral, in this case clarkeite, is produced. At 
relatively low $\mathrm{Na}^{+}$concentration in the reaction mixture, with the source of $\mathrm{Na}^{+}$coming from mostly the silicate precursor (sodium metasilicate nonahydrate), the predominant synthetic products are uranyl silicates. In this low sodium synthesis condition, only the reaction conditions (reagent mixing time and temperature, reflux time and temperature, and crystallization temperature and duration) and reaction solution $\mathrm{pH}$ determine the nature of the uranyl silicates produced. On the other hand, when the $\mathrm{Na}^{+}$concentration in the reaction mixture is raised above yet undefined $\mathrm{Na}^{+}$concentration, the end product, irrespective of synthesis conditions and $\mathrm{pH}$, is always a sodium uranate compound (clarkeite) and not the uranyl silicate.

The $\mathrm{Na}^{+}$concentration at SRS evaporators and evaporator feed tanks averages about 5.6 M. Based on the important roles played by $\mathrm{Na}^{+}$concentration in determining whether uranium silicate or clarkeite is produced during synthesis described so far, this will seem to suggest that the potential for the formation of any type of uranyl silicate minerals at SRS evaporators is relatively small. Based on the synthesis results in this study, one can simply conclude that clarkeite $\left(\mathrm{Na}\left[\left(\mathrm{UO}_{2}\right) \mathrm{O}(\mathrm{OH})\right]\left(\mathrm{H}_{2} \mathrm{O}\right)\right)$ is the predominant uranium mineral in the evaporators. This fact is supported by a recent characterization of evaporator scales ${ }^{27,} 28$, where the principal uranium mineral identified was sodium uranates, which is dehydrated clarkeite $\left(\mathrm{Na}_{2} \mathrm{U}_{2} \mathrm{O}_{7}\right)$. Therefore, this leads one to conclude that the recent observations. ${ }^{4,5}$ indicating the presence of possible uranyl silicate solid phases occluded in bulk aluminosilicate may be due to the presence of amorphous uranyl silicate mineral. Thus, crystalline uranyl silicates may be precluded from forming at high $\mathrm{Na}^{+}$concentrations but amorphous uranyl silicates may form at high sodium concentrations.

Therefore, based on the synthesis information presented in this study the following conclusions are made:

- Crystalline uranyl silicates are readily formed in the presence of dissolved uranium and silica.

- The presence of high $\mathrm{Na}^{+}$in a reaction mixture of dissolved uranium and silica inhibits the formation of uranyl silicates.

- The reaction path way favors the formation of sodium hydroxyl uranates over uranyl silicates in a reaction mixture with high $\mathrm{Na}^{+}$concentration.

- Crystalline uranyl silicate minerals are not easily produced under SRS evaporator conditions because of high $\mathrm{Na}^{+}$concentration in the evaporators and in the evaporator feed tanks.

- The principal uranium minerals which could be produced under evaporator conditions are sodium uranate minerals or clarkeite, which could also exist in the dehydrated forms called sodium uranates. 


\subsection{QUALITY ASSURANCE}

This study fulfills the activity defined in Task Technical and Quality Assurance Plan:

"Identification of Conditions Conducive to Forming Uranium Silicates in SRS Evaporators," WSRC-RP-2003-00387, Rev. 0, April 28, 2003. Data obtained from this study reside as records in WSRC-NB-99-00076.

\subsection{ACKNOWLEDGEMENTS}

The author thanks the Analytical Development Section personnel, in particular, A. R. Jurgensen and D. Messimer for XRD characterizations and Mrs. M. S. Blume for assistance in running the experiments. The author also thanks Dr. F. Fondeur and Mrs. S. McCullum for both Raman and IR characterization of the material made in this study. 


\subsection{REFERENCES}

${ }^{1}$ W. R. Wilmarth, S. D. Fink, D. T. Hobbs, and M. S. Hay, "Characterization and Dissolution Studies of Samples from the 242-16H Gravity Line," WSRC-TR-97-03326, October 16, 1997.

${ }^{2}$ W. R. Wilmarth, D. D. Walker, and S. D. Fink, "Sodium Aluminosilicate Formation in Tank 43H Simulant," WSRC-TR-97-00389, Nov. 15, 1997.

${ }^{3}$ D. T. Hobbs and T. B. Edwards, "Solubility of Uranium in Alkaline Salt Solutions," WSRC-TR-94-453, March 29, 1994.

${ }^{4}$ L. N. Oji and A. L. Williams, "Evaluation of the Incorporation of Uranium into Sodium Aluminosilicate Phases,"WSRC-TR-2002-00510, Rev. 0.0, November 26, 2002.

${ }^{5}$ M. C. Duff, D. B. Hunter, and L. N. Oji, "Characterization of Uranium Solids Precipitated with Aluminosilicates," WSRC-TR-2002-00527, Rev. 0.0, November 24, 2002.

${ }^{6}$ W. R. Wilmarth, C. J. Martino, J. T. Mills, and V. H. Dukes, "Results of Chemical Cleaning the 242-16H(2H) Evaporator at the Savannah River Site," WSRC-TR-200100412, August 31, 2001, Rev. 0.

${ }^{7}$ Reviews in Mineralogy, Volume 38: Uranium Mineralogy, Geochemistry and the Environment, 1999; P. C. Burns and R. Finch (eds.) Chapter 10: D. J. Wronkiewicz and E. C. Buck "Uranium Mineralogy and Geologic Disposal of Spent Nuclear Fuel," pg. 475-497.

${ }^{8}$ Reviews in Mineralogy, Volume 38: Uranium Mineralogy, Geochemistry and the Environment, 1999; P. C. Burns and R. Finch (eds.) Chapter 3: R. Finch and T. Murakami "Systematics and Paragenesis of Uranium Minerals," pg. 91-179.

${ }^{9}$ R. Iler,: The Chemistry of Silica, Chapters 2: "Water soluble silicates," pg. 116-171 and Chapter 3: "Polymerization of Silica," pg. 172-311, John Wiley \& Sons, New York, 1979.

${ }^{10}$ S. N. Nguyen et al., "Standard Gibbs free energies of formation at the temperature of $303.15 \mathrm{~K}$ of four uranyl silicates: soddyite, uranophane, sodium bolwoodite and sodium weeksite," J. Chemical Thermodynamics, Vol. 24, 359-376 (1992).

${ }^{11}$ F. Cesbron, P. Ildefonse, and M. Sichere, "New mineralogy data on uranophane and beta-uranophane; synthesis of uranophane," Mineralogical Magazine, Vol. 57, 301-308 (1993). 
${ }^{12}$ I. Perez, et al., "The thermodynamics and kinetics of uranophane dissolution in bicarbonate test solutions," Geochimica et Cosmochimica Acta. Vol. 64, 603-608, (2000).

${ }^{13}$ R. Vochten, L. Van Haverbeke and K. Van Springel, "Soddyite: Synthesis under elevated temperature and pressure, and study of some physicochemical properties;" N. Jb Miner Mh H, Vol. 10, 470-480 (1995).

${ }^{14}$ P. C. Burns, R. A. Olson, R. J. Finch, J. M. Hanchar, and Y. Thibault, " $\mathrm{KNa}_{3}\left(\mathrm{UO}_{2}\right)_{2}\left(\mathrm{Si}_{4} \mathrm{O}_{10}\right)_{2}\left(\mathrm{H}_{2} \mathrm{O}\right)_{4}$ a new compound formed during vapor hydration of an actinide-bearing borosilicate waste glass," Journal of Nuclear Materials, Vol. 278, 290300 (2000).

${ }^{15}$ F. Chen, R. C. Ewing, and S. B. Clark, "The Gibbs free energies and enthalpies of formation of $\mathrm{U}^{6+}$ phases: an empirical method of prediction," American Mineralogist, Vol. 84, 650 (1999).

${ }^{16}$ A. G. Sowder, S. B. Clark, and R. A. Fjeld, "The effects of silica and phosphate on the transformation of shoepite to becquerelite and other uranyl phases," Radiochim. Acta Vol. 74, 45-49 (1996).

${ }^{17}$ R. Finch and R. C. Ewing, "The corrosion of uraninite under oxidizing conditions," Journal of Nuclear Materials, Vol. 190, 133-156. (1992).

${ }^{18}$ S. Utsunomiya, L.-M. Wang, M. Douglas, S. B. Clark, and R. C. Ewing, "The effects of ionizing radiation on uranophane," American Mineralogist, Vol. 88, 159-166 (2003).

${ }^{19}$ L. W. Hobbs and M. R. Pascucci, "Radiolysis and defect structure in electron irradiated $\alpha$-quartz”, Journal de physique, 7, C6.237-C6.242 (1980).

${ }^{20}$ M. Deliens and P. Piret, "La Swamboite, nouveau silicate d'uranium hydrate du Shaba, Zaïre," Canadian Mineralogist, Vol. 19, 553-557 (1981).

${ }^{21}$ E. P. Plesko, B. E. Scheetz, and W. B. White, "Infrared vibrational characterization and synthesis of a family of hydrous alkali uranyl silicates and hydrous uranyl silicate minerals," American Mineralogist, Vol. 77, 431-437 (1992).

${ }^{22}$ J. Jackson and P. C. Burns, "The structure of weeksite: a potassium uranium silicate hydrate, Geol. Soc. America Annual Meeting. Abstract, 1999.

${ }^{23}$ L. H. Fuchs and H. R. Hoekstra, "The preparation and properties of uranium (IV) silicates," American Mineralogist, Vol. 44, 66-72 (1959).

${ }^{24}$ R. Vochten, N. Blaton, and O. Peeters, "Synthesis of sodium weeksite and its transformation into weeksite,” Neus Jb Miner Mh, Vol. 12, 569-576 (1997). 
${ }^{25}$ M. Amme, B. Renker, B. Schmid, M. P. Feth, H. Bertagnolli, and W. Dobelin, "Raman microspectrometric identification of corrosion products formed on $\mathrm{UO}_{2}$ nuclear fuel during leaching experiments," Journal of Nuclear Materials, Vol. 306, 202-212 (2002).

${ }^{26}$ Reviews in Mineralogy Volume 38: Uranium Mineralogy, Geochemistry and the Environment, 1999; P. C. Burns and R. Finch (eds.) Chapter 12: J. Cejka, "Infrared spectroscopy and thermal analysis of the uranyl minerals," pg. 521-622.

${ }^{27}$ W. R. Wilmarth, C. J. Coleman, A. R. Jurgensen, W. M. Smith, J. C. Hart, W. T. Boyce, D. Messimer, and C. M. Conley, "Characterization and Dissolution Studies of Samples from the 242-16H Evaporator," WSRC-TR-2000-00038, Jan. 16, 2000.

${ }^{28}$ W. R. Wilmarth, C. J. Coleman, J. C. Hart, and W. T. Boyce, "Characterization of Samples from the 242-16H Evaporator Wall," WSRC-TR-200-00089, March 20, 2000. 